\title{
Homoprejudiced violence among Chinese men who have sex with men: a cross- sectional analysis in Guangzhou, China
}

Dan $\mathrm{Wu}^{1,2^{*}}$, Eileen Yang ${ }^{2,3}$, Wenting Huang ${ }^{2,4}$, Weiming Tang ${ }^{2,5,6}$, Huifang $\mathrm{Xu}^{7}$, Chuncheng Liu ${ }^{8}$, Stefan Baral ${ }^{9}$, Suzanne Day ${ }^{3}$ and Joseph D. Tucker ${ }^{1,2,5}$

\begin{abstract}
Background: Homoprejudiced violence, defined as physical, verbal, psychological and cyber aggression against others because of their actual or perceived sexual orientation, is an important public health issue. Most homoprejudiced violence research has been conducted in high-income countries. This study examined homoprejudiced violence among men who have sex with men (MSM) in Guangzhou, China.

Methods: MSM in a large Chinese city, Guangzhou, completed an online survey. Data about experiencing and initiating homoprejudiced violence was collected. Multivariable logistic regression analyses, controlling for age, residence, occupation, heterosexual marriage, education and income, were carried out to explore associated factors.

Results: A total of 777 responses were analyzed and most (64.9\%) men were under the age of 30 . Threehundred-ninety-nine (51.4\%) men experienced homoprejudiced violence and 205 (25.9\%) men perpetrated homoprejudiced violence against others. Men who identified as heterosexual were less (AOR =0.6, 95\% Cl: 0.4-0.9) likely to experience homoprejudiced violence compared to men who identified as gay. Men who experienced homoprejudiced violence were more likely to initiate homoprejudiced violence (AOR $=2.44,95 \%$ Cl: 1.6-3.5). Men who disclosed their sexual orientation to other people were more likely to experience homoprejudiced violence (AOR $=1.8,95 \% \mathrm{Cl}: 1.3-2.5$ ).
\end{abstract}

Conclusions: These findings suggest the importance of further research and the implementation of interventions focused on preventing and mitigating the effects of homoprejudiced violence among MSM in China.

Keywords: Epidemiology, Stigma, Homoprejudice, Violence, Men who have sex with men, China

\section{Background}

Homoprejudiced violence is a major public health issue [1]. Homoprejudiced violence is defined as physical, verbal, psychological, and cyber aggression against an

\footnotetext{
* Correspondence: dan.wu@lshtm.ac.uk

${ }^{1}$ International Diagnostics Centre, London School of Hygiene and Tropical Medicine, Keppel Street, Bloomsbury, London WC1E 7HT, UK

${ }^{2}$ Social Entrepreneurship to Spur Health (SESH) Global, Guangzhou, China Full list of author information is available at the end of the article
}

individual, group or community based on their actual or perceived sexual orientation [2-6]. Homoprejudiced violence can be directed at people who identify as sexual minorities or those who are perceived as being a sexual minority.

The United Nations (UN) has recognized homoprejudiced violence as an important public health problem [4]. Homoprejudiced violence can result in physical and psychological harm, decreased productivity, and

(c) The Author(s). 2020 Open Access This article is licensed under a Creative Commons Attribution 4.0 International License, which permits use, sharing, adaptation, distribution and reproduction in any medium or format, as long as you give appropriate credit to the original author(s) and the source, provide a link to the Creative Commons licence, and indicate if changes were made. The images or other third party material in this article are included in the article's Creative Commons licence, unless indicated otherwise in a credit line to the material. If material is not included in the article's Creative Commons licence and your intended use is not permitted by statutory regulation or exceeds the permitted use, you will need to obtain permission directly from the copyright holder. To view a copy of this licence, visit http://creativecommons.org/licenses/by/4.0/ The Creative Commons Public Domain Dedication waiver (http://creativecommons.org/publicdomain/zero/1.0/) applies to the data made available in this article, unless otherwise stated in a credit line to the data. 
increased risk of addictions (e.g., substance and alcohol use) [4, 6-9]. However, homoprejudiced violence is often under-reported because victims are afraid of disclosing their sexual orientation [10] and there are limited resources for survivors $[9,11]$.

There is less research on homoprejudice in low- and middle-income countries (LMICs) [12, 13], including China [4]. One Chinese study found that $40.7 \%$ of sexual minorities experienced name calling, $34.8 \%$ were verbally abused, $22.4 \%$ were isolated in school, and $6.0 \%$ received physical violence threats [6]. Furthermore, existing evidence is focused more broadly on sexual minorities as a whole [9]. Previous research on LGBT youth in the United States reported that gay men are at higher risk of ostracization and receiving homoprejudiced remarks compared to lesbian and bisexual subgroups $[14,15]$. However, little is known about the experiences of homoprejudiced violence among gay men or other men who have sex with men (MSM). Discrimination and homoprejudiced violence are known to influence sexual orientation disclosure $[7,10,16]$ and uptake of HIV and other sexual health services [17]. A study in the United States reported that homoprejudiced violence victimization during youth was associated with more condomless sex and higher risk of HIV during adulthood [18].

Homoprejudiced violence initiated by gay men has not been well studied [9]. Many people who do not conform to gender and sexual norms are stigmatized, especially among men [14]. Masculinity is a primary component of socially desirable gender expression for men, and according to Connell's theory of hegemonic masculinity, aggression is a feature of masculinity $[19,20]$. As a result, both heterosexual men and closeted gay men may act in an aggressive way towards gay people to demonstrate their masculinity and differentiate themselves from gay men. Some gay men are afraid of receiving homoprejudiced violence and in order to hide their sexual orientation, show aggressive behaviors against LGBT groups to reinforce their masculinity $[6,9]$. Understanding homoprejudiced violence may help to improve resources and develop interventions. The purpose of this study was to examine the frequency and correlates of homoprejudiced violence among MSM in Guangzhou, China.

\section{Material and methods \\ Online survey}

In partnership with a local community-based organization ( $\mathrm{CBO}$ ) and the Guangzhou Center for Disease Control and Prevention (CDC), we conducted a cross-sectional online questionnaire survey with 777 MSM in Guangzhou, China in September 2018. The survey was distributed online to MSM through $\mathrm{CBO}$ and CDC social media accounts. Eligibility criteria included the following: being biologically male at birth; being 16 years old or above; reported ever having oral or anal sex with men; residing in Guangzhou in the past six months. All survey data were anonymous and confidential, and online consent was obtained prior to the survey. Each man who participated received either 7.5 USD (50 Chinese Yuan) or a free HIV self-test kit as an incentive to participate.

\section{Survey instruments}

We collected information about participants' sociodemographic characteristics including age, residence permit, occupation, heterosexual marital status (never married, engaged or married, and divorced/separated/widowed), annual income, highest education obtained (high school or less, some college, university, and postgraduate), gender identity (male, female, transgender, and unsure), sexual orientation (gay, bisexual, heterosexual, and unsure) and sexual orientation disclosure to people other than their partner(s) (yes/no).

\section{Homoprejudiced violence questionnaire}

Twelve homoprejudiced violence survey items were designed based on previous literature [5, 21, 22]. We selected 12 items to cover four domains - physical assault, verbal aggression, psychological abuse, and cyber violence (Supplementary file 1). We translated and adapted the 12 items in order for them to be relevant to Chinese men. These 12 items asked whether a participant had ever experienced any of the following due to their sexual orientation: being gossiped about, being name called, being deliberately alienated or isolated, being threatened, being maliciously called gay, being spat on, having personal belongings damaged, being deprived of economic resources or personal belongings by someone (including family members), having personal freedom restricted by someone (including family members), being physically harmed (such as being slapped, beaten or kicked), being harmed on social media (such as WeChat and Weibo, the Chinese substitutes of WhatsApp and Twitter), and being harmed through phone calls or messages. The items were field tested with 10 participants and minor amendments were made for better clarity.

All 12 items used three responses: "yes", "no" and "do not want to tell". A new summative variable was generated by adding up the responses ("yes" were coded as 1 , "no" or "do not want to tell" were coded as 0) of the 12 items to assess the overall prevalence. The summed value 0 was recoded as 0 (no prior experiences of homoprejudiced violence), and the summed values 1 to 12 were recoded as 1 (prior experiences of homoprejudiced violence of any type) (outcome 1). Additionally, one 
follow-up item asked whether participants had ever committed any of the 12 violent behaviors aforementioned against others due to their sexual orientation (yes, no, do not want to tell) (outcome 2). The Cronbach alpha value of the 12-item homoprejudiced violence questionnaire was 0.89 .

\section{Data analysis}

Descriptive analysis was used to describe sample characteristics, including sociodemographic backgrounds and frequencies of violence experiences. The two outcomes were dichotomized (with "no" and "do not want to tell" grouped together) in regression analyses. We conducted univariate and multivariable binary logistic regressions to examine sociodemographic factors associated with homoprejudiced violence. We reported odds ratios and 95\% confidence intervals (CIs). Data were analyzed using SPSS, version 25 .

\section{Results}

We invited 2691 MSM to participate in the survey and 917 completed the questionnaire (response rate = 34\%). Overall, 140 of these 917 MSM did not meet inclusion criteria and were excluded from the analysis. Data from 777 men were included in the analysis. Table 1 shows sociodemographic characteristics of the sample. Over half of survey respondents were under the age of $30(495,64.9 \%)$ and self-identified as gay $(447,57.5 \%)$. Most men lived in urban areas (639, $82.2 \%)$. A large proportion of men were not students $(718,92.4 \%)$, and about half had obtained universitylevel education or above (440, 56.7\%). Around 40\% (313) of men earned an annual income between US\$8682-13,024, and nearly three-quarters had never been engaged or married to a woman (574, 73.9\%). Most men had disclosed their sexual orientation to people other than their partners $(571,73.5 \%)$. A total of 399 (51.4\%) men reported experiences of homoprejudiced violence, while 205 (25.9\%) men initiated homoprejudiced violence (Fig. 1). Frequencies of each violence item are reported in Table 2. One hundred and six men (13.4\%) experienced physical violence. One hundred and eighty-three men (23.1\%) experienced name calling. Two hundred men (25.2\%) experienced social isolation. One hundred and thirteen men (14.2\%) experienced deprivation of economic resources or personal belongings and 128 (16.1\%) reported cyber violence on social media.

After controlling for demographic variables including age, residence status, occupation, marital status, education level, and annual income, multivariable logistic regression analyses showed that men who identified as heterosexual were less $(\mathrm{AOR}=0.6,95 \%$
CI: 0.4-0.9) likely to experience homoprejudiced violence compared to men who identified as gay.Men who were unsure about their sexual orientation were more likely ( $\mathrm{AOR}=2.6,95 \% \mathrm{CI}: 1.2-5.5)$ to have experienced homoprejudiced violence compared to gay men (Table 3). Men who disclosed their sexual orientation were,more likely $(\mathrm{AOR}=1.8,95 \% \mathrm{CI}$ : 1.3-2.5) to experience homoprejudiced violence compared to other men (Table 3).

Men younger than 30 years old were more likely to have initiated homoprejudiced violence against others compared to older men $(\mathrm{AOR}=2.4,95 \% \mathrm{CI}$ : 1.5-3.8) (Table 3). Urban men were also more likely to have initiated homoprejudiced violence compared to rural men $(\mathrm{AOR}=2.9,95 \% \mathrm{CI}$ : 1.6-5.2). Men who were engaged or married to women were more likely $(\mathrm{AOR}=5.7,95 \% \mathrm{CI}: 3.6-9.1)$ to have initiated homoprejudiced violence than those who had never been married. Men who were separated, divorced, or widowed were more likely $(\mathrm{AOR}=9.2$, 95\% CI: $4.8-$ 17.6) to have initiated homoprejudiced violence compared to other men. People who identified as women or transgender/unsure were found to be 3.0 times $(\mathrm{AOR}=3.0,95 \% \mathrm{CI}: 1.5-6.2)$ and 2.2 times $(\mathrm{AOR}=$ 2.2, 95\% CI: $1.2-4.2)$ more likely to have been a perpetrator, respectively. Respondents who ever experienced homoprejudiced violence before were 2.4 times $(\mathrm{AOR}=2.4,95 \% \mathrm{CI}: 1.6-3.5)$ more likely to have initiated homoprejudiced violence against others.

\section{Discussion}

Homoprejudiced violence among sexual minorities is an important public health issue in many LMICs. Our study contributes to the literature by examining homoprejudiced violence among MSM in China, including MSM-initiated homoprejudiced violence .

We found that approximately half of men had ever experienced some form of homoprejudiced violence. This is lower than the prevalence of homoprejudiced violence observed in the UK [9] and US [11, 23]. Less homoprejudiced violence in Guangzhou may be related to lower levels of disclosing sexual orientation [24]. This finding is consistent with studies showing that more visible LGBT people may suffer from higher levels of violence $[25,26]$. Interventions to reduce discrimination against sexual minorities are needed in China.

Many MSM in our sample who experienced homoprejudiced violence then went on to initiate homoprejudiced violence against other MSM. This finding is consistent with a study from the United States [27]. MSM may use violence as an approach to conceal their sexual orientation if they have been a victim of 
Table 1 Sample characteristics of MSM who have experienced/engaged in homoprejudiced violence in Guangzhou, China in 2018 $(N=777)$

\begin{tabular}{|c|c|c|c|c|}
\hline & & Total & $\begin{array}{l}\text { Ever experienced } \\
\text { homoprejudiced violence }\end{array}$ & $\begin{array}{l}\text { Ever perpetrated homoprejudiced } \\
\text { violence against others }\end{array}$ \\
\hline & & $N=777(\%)$ & $N=399(\%)$ & $N=205(\%)$ \\
\hline \multirow{2}{*}{ Age (years) } & $<30$ & $495(64.9)$ & $243(62.1)$ & $128(63.7)$ \\
\hline & $30-39$ & $268(35.1)$ & $148(37.9)$ & $73(36.3)$ \\
\hline \multirow[t]{2}{*}{ Residence permit $^{\dagger}$} & Rural & $138(17.8)$ & $58(14.5)$ & $18(8.8)$ \\
\hline & Urban & $639(82.2)$ & $341(85.5)$ & $187(91.2)$ \\
\hline \multirow[t]{2}{*}{ Occupation } & Non-student & $718(92.4)$ & $369(92.5)$ & $197(96.1)$ \\
\hline & Student & $59(7.6)$ & $30(7.5)$ & $8(3.9)$ \\
\hline \multirow[t]{3}{*}{ Marital status with a woman } & Never married & $574(73.9)$ & $279(69.9)$ & $102(49.8)$ \\
\hline & Engaged or married & $139(17.9)$ & $82(20.6)$ & $68(33.2)$ \\
\hline & Separated, divorced or widowed & $64(8.2)$ & $38(9.5)$ & $35(17.1)$ \\
\hline \multirow[t]{3}{*}{ Highest education level } & High school or below & $82(10.6)$ & $36(9.0)$ & $13(6.3)$ \\
\hline & Some college & $255(32.8)$ & $111(27.8)$ & $81(39.5)$ \\
\hline & University or above & $440(56.7)$ & $252(63.2)$ & $111(54.2)$ \\
\hline \multirow{3}{*}{ Annual income (USD) } & $<8682$ & $231(29.7)$ & $103(25.8)$ & $38(18.5)$ \\
\hline & $8682-13024$ & $313(40.3)$ & $174(43.6)$ & $111(54.1)$ \\
\hline & $>13024$ & $233(29.9)$ & $122(30.6)$ & $56(27.4)$ \\
\hline \multirow[t]{3}{*}{ Gender } & Male & $675(86.9)$ & $339(85.0)$ & $149(72.7)$ \\
\hline & Female & $46(5.9)$ & $23(5.8)$ & $28(13.7)$ \\
\hline & Transgender/unsure & $39(5.0)$ & $37(9.3)$ & $28(13.7)$ \\
\hline \multirow[t]{4}{*}{ Sexual orientation } & Gay & $447(57.5)$ & $222(55.6)$ & $90(43.9)$ \\
\hline & Bisexual & $175(22.5)$ & $106(26.6)$ & $79(38.5)$ \\
\hline & Heterosexual & $116(14.9)$ & $43(10.8)$ & $29(14.1)$ \\
\hline & Unsure/other & $39(5.0)$ & $28(7.0)$ & $7(3.4)$ \\
\hline Sexual orientation disclosure ${ }^{\ddagger}$ & Yes & $571(73.5)$ & $317(79.4)$ & $189(92.2)$ \\
\hline \multirow{2}{*}{$\begin{array}{l}\text { Ever experienced homoprejudiced } \\
\text { violence }\end{array}$} & No & $378(48.6)$ & & $68(33.2)$ \\
\hline & Yes & $399(51.4)$ & & $137(66.8)$ \\
\hline \multicolumn{5}{|l|}{$1 \%$ : valid percentages used } \\
\hline \multicolumn{5}{|c|}{$2{ }^{\dagger}$ Based on Hukou, the Chinese household registration system } \\
\hline \multicolumn{5}{|c|}{${ }^{\ddagger}$ Sexual orientation disclosure to others besides sexual partners } \\
\hline
\end{tabular}

homoprejudiced violence [9]. Other potential factors may include poor sexual education and fear of social stigma. Poor awareness of homoprejudiced violence might also play a role. Understanding the context of homoprejudiced violence is key to successfully creating an environment where all MSM feel safe.

The data presented here have implications for research and policy. There are few epidemiological studies focusing on homoprejudiced violence among MSM in LMICs. Our study provides evidence on the prevalence and correlates of homoprejudiced violence. In terms of designing interventions, some subsets of MSM may be at greater risk for homoprejudiced violence. Our study suggests that younger, urban, and openly gay men are more likely to initiate homoprejudiced violence against others. Given young gay men are more often engaged in community-based sexual health programs, there may be missed opportunities for engaging communitybased organizations to develop anti-violence interventions.

Our findings should be interpreted in the context of several limitations. First, we conducted the survey with MSM who subscribed to the social media account of a community-based organization that provided sexual health services in a developed city in 


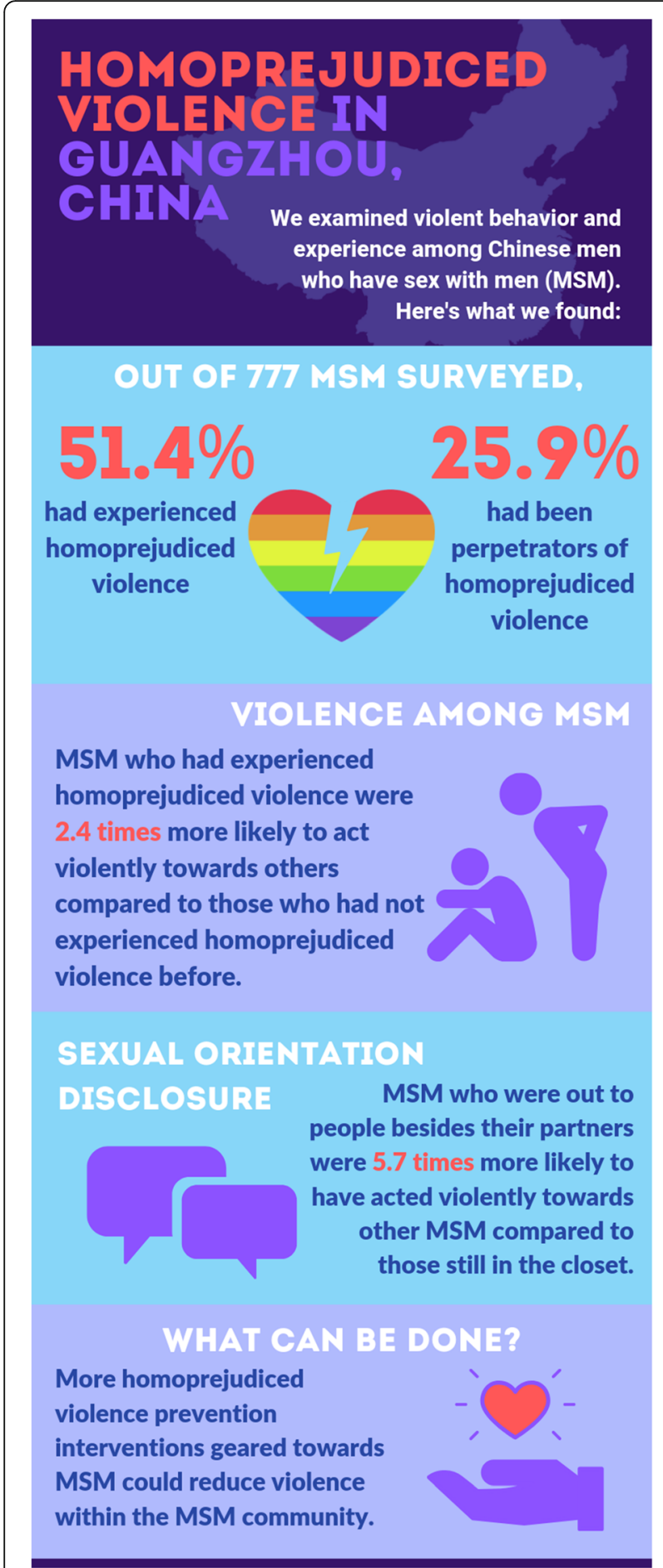

Fig. 1 Infographic of homoprejudiced violence in Guangzhou, China. Source of data: The authors created this infographic based on the study findings by using a free graphic design website Canva (https://www.canva.com/)
Table 2 Frequency of individual homoprejudiced violence items $n(\%)$

\begin{tabular}{ll}
\hline Individual items & Yes \\
\hline $\begin{array}{l}\text { 1. Have you ever been gossiped due to your sexual } \\
\text { orientation? }\end{array}$ & $217(27.4)$ \\
$\begin{array}{l}\text { 2. Have you ever experienced name calling due to } \\
\text { your sexual orientation? }\end{array}$ & $183(23.1)$
\end{tabular}

3. Have you ever been deliberately alienated or isolated 200 (25.2) due to your sexual orientation?

4. Have you ever been threatened due to your sexual orientation?

5. Have you ever been maliciously called gay due to your sexual orientation?

6. Have you ever been spat on due to your sexual orientation?

7. Did anyone damage your personal belongings due to your sexual orientation?

8. Have you ever been deprived of economic resources or personal belongings by anyone (including your family members) due to your sexual orientation?

9. Have you ever been restricted on personal freedom by anyone (including your family members) due to your sexual orientation?

10. Have you ever been physically harmed, such as be being slapped, beaten or kicked due to your sexual orientation?

11. Have you ever been harmed on social media (such as WeChat, Weibo) due to your sexual orientation?

12. Have you ever been harmed by phone call or messages due to your sexual orientation?

Total respondents who experienced any of the above violence

$103(13.0)$

$190(24.0)$

$106(13.4)$

$102(12.9)$

$106(13.4)$

$128(16.1)$

$126(15.9)$

$399(51.4)$

China. Our participants had higher education and income than the average Guangzhou resident. Our study results should not be extrapolated to the wider community of MSM in China. Second, we combined participants' responses of "no" and "don't want to tell" to homoprejudiced violence as one category. This may result in a conservative or underestimate of the actual prevalence of homoprejudiced violence experiences due to unwillingness to share. Third, the study focused on homoprejudiced violence, but not broader experiences of homoprejudice. It is likely that non-violent experiences of homoprejudice among MSM are even more prevalent (e.g. social exclusion). Fourth, we recruited MSM who ever had anal or oral sex with a man in the study but did not include those who were gay men but had never engaged in sex with a man, limiting our understanding of the experiences of homoprejudiced violence to a subset of sexually active MSM. Lastly, an online cross-sectional questionnaire survey has limited depth to fully understand men's thoughts about their 
Table 3 Factors associated with experiencing homoprejudiced violence/ever violating others among MSM in Guangzhou, China, in $2018(N=777)$

\begin{tabular}{|c|c|c|c|c|c|}
\hline & & \multicolumn{2}{|c|}{$\begin{array}{l}\text { Ever experienced homoprejudiced } \\
\text { violence }\end{array}$} & \multicolumn{2}{|c|}{$\begin{array}{l}\text { Ever perpetrated homoprejudiced violence } \\
\text { against others }\end{array}$} \\
\hline & & $\mathrm{COR}$ & AOR & $\mathrm{COR}$ & AOR \\
\hline \multicolumn{6}{|c|}{ Demographic factors (AORs: including demographic variables only in the modeling) } \\
\hline \multirow[t]{2}{*}{ Age (years) } & $<30$ & $0.8(0.6-1.1)$ & $0.9(0.6-1.2)$ & $0.9(0.7-1.3)$ & $2.4(1.5-3.8)^{* * *}$ \\
\hline & $>=30$ & 1 & 1 & 1 & 1 \\
\hline \multirow[t]{2}{*}{ Residence permit $^{\dagger}$} & Rural & 1 & 1 & 1 & 1 \\
\hline & Urban & $1.6(1.1-2.3)^{*}$ & $1.5(0.99-2.2)$ & $2.8(1.6-4.7)^{* * *}$ & $2.9(1.6-5.2)^{* * *}$ \\
\hline \multirow[t]{2}{*}{ Occupation } & Non-student & 1 & 1 & & \\
\hline & Student & $1.0(0.6-1.7)$ & $1.2(0.7-2.2)$ & & \\
\hline \multirow[t]{3}{*}{ Marital status } & Never married & 1 & 1 & 1 & 1 \\
\hline & Engaged or married & $1.5(1.0-2.2)^{*}$ & $1.5(0.99-2.2)$ & $4.4(3.0-6.6)^{* * *}$ & $5.7(3.6-9.1)^{* * *}$ \\
\hline & Separated, divorced or widowed & $1.5(0.9-2.6)$ & $1.7(0.9-2.9)$ & $5.6(3.3-9.6)^{* * *}$ & $9.2(4.8-17.6)^{* * *}$ \\
\hline \multirow[t]{3}{*}{ Highest education level } & High school or below & $0.6(0.4-0.9)^{*}$ & $0.6(0.4-1.1)$ & $0.6(0.3-1.0)$ & $0.8(0.4-1.6)$ \\
\hline & Some college & $0.6(0.4-0.8)^{* * *}$ & $0.6(0.4-0.8)$ & $1.4(1.0-1.9)$ & $1.5(0.99-2.2)$ \\
\hline & University or above & 1 & 1 & 1 & 1 \\
\hline \multirow[t]{3}{*}{ Annual income (USD) } & $<8682$ & $0.7(0.5-1.1)$ & $1.0(0.6-1.5)$ & $0.6(0.4-0.99)^{*}$ & $0.6(0.3-1.1)$ \\
\hline & $8682-13024$ & $1.1(0.8-1.6)$ & $1.3(0.9-1.9)$ & $1.7(1.2-2.5)^{* *}$ & $1.7(1.1-2.6)^{*}$ \\
\hline & $>13024$ & 1 & 1 & 1 & 1 \\
\hline \multicolumn{6}{|c|}{ AORs: controlling for age, residence permit, occupation, marital status, education level, and monthly income } \\
\hline \multirow[t]{3}{*}{ Gender identity } & Male & 1 & 1 & 1 & 1 \\
\hline & Female & $1.0(0.5-1.8)$ & $0.9(0.5-1.7)$ & $5.5(3.0-10.2)^{* * *}$ & $3.0(1.5-6.2)^{* *}$ \\
\hline & Transgender/unsure & $1.9(1.1-3.4)^{*}$ & $1.6(0.9-3.0)$ & $3.5(2.0-6.1)^{* * *}$ & $2.2(1.2-4.2)^{*}$ \\
\hline \multirow[t]{4}{*}{ Sexual orientation } & Gay & 1 & 1 & & \\
\hline & Bisexual & $1.6(1.1-2.2)^{*}$ & $1.2(0.8-1.8)$ & & \\
\hline & Heterosexual & $0.6(0.4-0.9)^{*}$ & $0.6(0.4-0.9)^{*}$ & & \\
\hline & Unsure/other & $2.6(1.3-5.3)^{*}$ & $2.6(1.2-5.5)^{*}$ & & \\
\hline \multirow[t]{2}{*}{ Sexual orientation disclosure ${ }^{\ddagger}$} & No & 1 & 1 & 1 & 1 \\
\hline & Yes & $1.9(1.4-2.6)^{* * *}$ & $1.8(1.3-2.5)^{* *}$ & $5.9(3.4-10.1)^{* * *}$ & $5.7(3.2-10.2)^{* * *}$ \\
\hline \multirow{2}{*}{$\begin{array}{l}\text { Ever experienced } \\
\text { homoprejudiced violence }\end{array}$} & No & & & 1 & 1 \\
\hline & Yes & & & $2.4(1.7-3.3) * * *$ & $2.4(1.6-3.5) * * *$ \\
\hline \multicolumn{6}{|c|}{ COR: Crude odds ratio; AOR: Adjusted odds ratio } \\
\hline \multicolumn{6}{|c|}{${ }^{\dagger}$ Based on Hukou, the Chinese household registration system } \\
\hline \multicolumn{6}{|c|}{${ }^{\ddagger}$ Sexual orientation disclosure to others besides sexual partners } \\
\hline \multicolumn{6}{|c|}{$*$ : p-value $<0.05 ; * *$ : p-value $<0.01 ; * * *$ p -value $<0.00$} \\
\hline
\end{tabular}

own experiences. Qualitative research is warranted to better understand the issue.

\section{Conclusions}

Homoprejudiced violence is an important public health problem. We found high a prevalence of homoprejudiced violence victimization and perpetration among Chinese MSM. Interventions are necessary to prevent homoprejudiced violence among Chinese MSM and create an environment where MSM feel safe.

\section{Supplementary information}

Supplementary information accompanies this paper at https://doi.org/10 1186/s12889-020-08540-9

Additional file 1. Homoprejudiced violence questionnaire

\section{Abbreviations}

MSM: Men who have sex with men; LMIC: Low- and middle-income countries 


\section{Acknowledgements}

Not applicable.

\section{Authors' contributions}

D.W. conceived the idea and designed the study. W.H., W.T., and H.X coordinated and collected data. W.H. cleaned the data. D.W. and E.Y. analyzed the data. D.W., E.Y., and J.D. wrote the paper. W.H., W.T., C.L., S.B., S.D., and H.X. provided constructive comments and edited the paper. All authors reviewed and approved the final version of the paper.

\section{Funding}

This work received funding support from Academy of Medical Sciences and the Newton Fund (Grant number NIF\R1\181020), National Institutes of Health (NIAID 1R01Al114310-01), UNC-South China STD Research Training Center (FIC 1D43TW009532-01), UNC Center for AIDS Research (NIAID 5P30AI050410), the North Carolina Translational \& Clinical Sciences Institute (1UL1TR001111), and SMU Research Initiation Project (QD2017N030, C1034448). The funders played no role in study design, data collection, analysis and interpretation of data, or in the writing of the article.

\section{Availability of data and materials}

The datasets used and/or analyzed during the current study are available from the corresponding author on reasonable request.

\section{Ethics approval and consent to participate}

Ethical approval was obtained from Guangzhou Center for Diseases Contro and Prevention. Online informed consent was obtained prior to the commencement of the survey questionnaire. The form of consent was approved by the ethics committee.

\section{Consent for publication}

Not applicable

\section{Competing interests}

The authors declare that they have no competing interests.

\section{Author details}

${ }^{1}$ International Diagnostics Centre, London School of Hygiene and Tropical Medicine, Keppel Street, Bloomsbury, London WC1E 7HT, UK. ${ }^{2}$ Social Entrepreneurship to Spur Health (SESH) Global, Guangzhou, China. ${ }^{3}$ Institute for Global Health and Infectious Diseases, University of North Carolina at Chapel Hill, Chapel Hill, North Carolina, USA. " Behavioral Sciences and Health Education, Rollins School of Public Health, Emory University, Atlanta, GA, USA ${ }^{5}$ University North Carolina at Chapel Hill, Project-China, Guangzhou, China. ${ }^{6}$ Dermatology Hospital of Southern Medical University, Guangzhou, China. ${ }^{7}$ Guangzhou Center of Diseases Control, Guangzhou, China. ${ }^{8}$ Department of Sociology, University of California San Diego, San Diego, USA. ${ }^{9}$ Department of Epidemiology, The Johns Hopkins School of Public Health, Baltimore, MD, USA.

Received: 8 December 2019 Accepted: 17 March 2020

Published online: 27 March 2020

\section{References}

1. Srabstein JC, Leventhal BL. Prevention of bullying-related morbidity and mortality: a call for public health policies. SciELO Public Health. Bulletin of the World Health Organization 2010;88:403. https://doi.org/10.2471/BLT.10. 077123.

2. Rutherford A, Zwi AB, Grove NJ, Butchart A. Violence: a glossary. J Epidemiol Community Health. 2007;61(8):676-80.

3. The Rainbow Project. Bullying Belfast: The Rainbow Project; 2019 [cited 2019 4 June]. Available from: https://www.rainbow-project.org/bullying.

4. UNESCO. Review of homophobic bullying in educational institutions Paris: United Nations Educational, Scientific and Cultural Organization; 2012 [cited 20192 June]. Available from: https://unesdoc.unesco.org/ark:/48223/ pf0000215708.

5. Amankavičiūte S. Sexual orientation and gender identity based bullying in Lithuanian schools: Survey data analysis2014; ILGA-Europe. Available from: https://www.lga-europe.org/sites/default/files/Attachments/lt__report en_-_house_of_diversity.pdf.
6. C-z W, W-I L. The association between school bullying and mental health of sexual minority students. Chinese J Clin Psychol. 2015:23(4):701-5.

7. Formby E. The impact of homophobic and transphobic bullying on education and employment: a European survey 2013. Sheffield: Sheffield Hallam University; 2013.

8. Lea T, de Wit J, Reynolds R. Minority stress in lesbian, gay, and bisexual young adults in Australia: associations with psychological distress, suicidality, and substance use. Arch Sex Behav. 2014;43(8):1571-8.

9. Highland Council Psychological Services. A Whole-School study of the extent and impact of homophobic bullying Highland2014 [cited 20194 June]. Available from: https://www.highland.gov.uk/download/downloads/ id/12122/homophobic_bullying_report_november_2014.pdf.

10. Takács J. Social exclusion of young lesbian, gay, bisexual and transgender (LGBT) people in Europe: ILGA Europe Brussels. Belgium; 2006.

11. Kosciw JG, Greytak EA, Zongrone AD, Clark CM, Truong NL. The 2017 National School Climate Survey: the experiences of lesbian, gay, bisexual, transgender, and queer youth in our Nation's schools: ERIC; 2018.

12. Ireland PR. A macro-level analysis of the scope, causes, and consequences of homophobia in Africa. Afr Stud Rev. 2013:56(2):47-66.

13. Spijkerboer T. Fleeing homophobia: sexual orientation, gender identity and asylum: Routledge; 2013.

14. Katz-Wise SL, Rosario M, Tsappis M. Lesbian, gay, bisexual, and transgender youth and family acceptance. Pediatr Clin N Am. 2016;63(6):1011-25.

15. Kosciw JG, Greytak EA, Diaz EM. Who, what, where, when, and why: demographic and ecological factors contributing to hostile school climate for lesbian, gay, bisexual, and transgender youth. J Youth Adolesc. 2009; 38(7):976-88.

16. Hollis LP, McCalla SA. Bullied back in the closet: disengagement of LGBT employees facing workplace bullying. J Psychol Issues Organ Cult. 2013;4(2) 6-16.

17. Johnson CA. Off the map. How HIV/AIDS programming is failing same-sex practicing people in Africa New York: International Gay and Lesbian Human Rights Commission; 2007 [cited 201921 August 2019]. Available from: https://outrightinternational.org/sites/default/files/6-1.pdf.

18. Friedman MS, Marshal MP, Stall R, Cheong J, Wright ER. Gay-related development, early abuse and adult health outcomes among gay males. AIDS Behav. 2008:12(6):891-902.

19. Connell RW. Gender and power: society, the person and sexual politics: John Wiley \& Sons; 2013.

20. Connell RW. Masculinities: polity; 2005.

21. Hinduja S, Patchin JW. Cyberbullying research summary: Bullying, cyberbullying, and sexual orientation. Cyberbullying Research Center: http:// cyberbullying org/cyberbullying_sexual_orientation_fact_sheet pdf. 2011.

22. Evans CB, Chapman MV. Bullied youth: the impact of bullying through lesbian, gay, and bisexual name calling. Am J Orthop. 2014;84(6):644.

23. Hightow-Weidman LB, Phillips G, Jones KC, Outlaw AY, Fields SD. Smith fTYOCSISG, Justin C. racial and sexual identity-related maltreatment among minority YMSM: prevalence, perceptions, and the association with emotional distress. AIDS Patient Care STDs. 2011;25(S1):S39-45.

24. Liu JX, Choi K. Experiences of social discrimination among men who have sex with men in Shanghai, China. AIDS Behavior. 2006;10(1):25-33.

25. Stahnke T, LeGendre P, Grekov I, Petti V, McClintock M, Aronowitz A. Violence Based on Sexual Orientation and Gender Identity Bias; 2008.

26. Human Rights Watch. "We Need a law for Liberation": Gender, Sexuality and Human Rights in a Changing Turkey 2008 [cited 201920 June]. Available from: https://www.hrw.org/reports/2008/turkey0508/

27. Ma X. Bullying and being bullied: to what extent are bullies also victims? Am Educ Res J. 2016;38(2):351-70.

\section{Publisher's Note}

Springer Nature remains neutral with regard to jurisdictional claims in published maps and institutional affiliations. 